\title{
The beauty of spiritual leadership: A theological- aesthetical approach to leadership
}

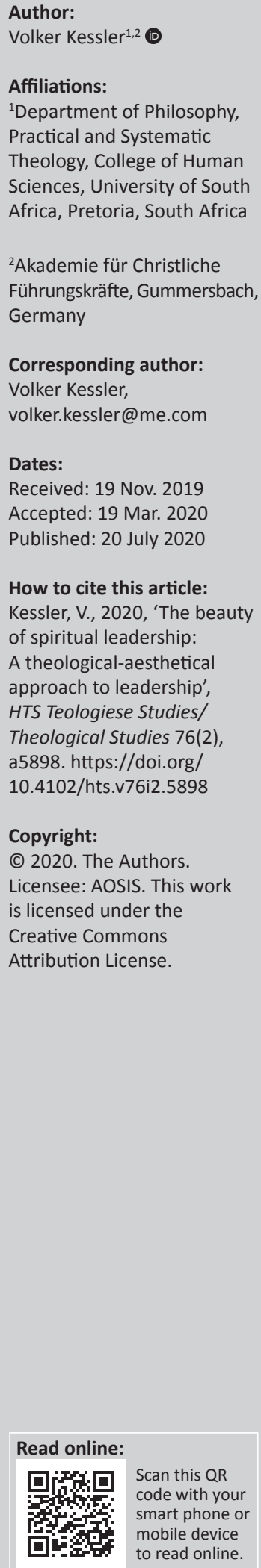

The aim of this article is to investigate two links between beauty and leadership: What is beautiful about spiritual leadership? Why should spiritual leaders bother about beauty? This study was motivated by the Bible verse 1 Timothy 3:1 and the observation that, at least in the German context, church leadership is no longer seen as a beautiful task. After a preliminary note on theological aesthetics, the paper discusses several approaches towards the link between aesthetics and transformation of the world, among them God becoming beautiful by Rudolf Bohren and Christianity, art and transformation by John de Gruchy. The article finally argues that: (1) spiritual leaders are beautifying the church and beyond and (2) spiritual leaders should strive for beauty as diligently as they strive for truth and goodness. Statement (1) is drawn from the propositions that (a) the spirit is the real leader of the church, (b) church leaders are partaking in the work of the spirit and (c) the spirit is beautifying the church and beyond. This is a theological statement, not a phenomenological one. A small poll provides some answers to the questions: 'what is beautiful about leading?' and 'what is not beautiful about leading?' An example of a German kindergarten illustrates some benefits of an aesthetical approach.

Contribution: This article focuses on the neglected area of aesthetics in the context of leadership. It aims to encourage Christian leaders to fight against the ugliness of the world and make the world more beautiful.

Keywords: Aesthetics; Spiritual leadership; Church leadership; Holy Spirit; Beautifying; Transformation; Practical theology; Rudolf Bohren; John de Gruchy; Patrick Sherry.

\section{Introduction}

'What is beautiful about leadership?' This question entered my mind whilst I was reading 1 Timothy 3:1 in my German Bible, which describes church leadership as a 'beautiful task' ('schöne Aufgabe'). The English standard version reads, 'if anyone aspires to the office of overseer, he desires a noble task'. The Greek word is kalos, which can be translated as 'good' or as 'beautiful'. Most English Bible translations explain it as 'a good task' or 'a noble task'. There are (at least) four German Bible translations using the word 'schön' ${ }^{1}$ and two French Bible translations using the word 'belle'. 'Two German Bible commentaries opt for the translation 'schön' and discuss the beauty of the leadership task (Grünzweig 1996:118-119; Roloff 1988:148, 153).

1 Timothy 3:1 is the starting point of a longer section about appointing the right persons as 'overseers', referring to the leadership in a local parish (Roloff 1988:153). The task of church leadership is important and carries considerable responsibility; therefore an overseer needs several qualifications (verses 2-7, similar to the list of virtues in Tt 1:6-9). It can also be a hard task, challenged by God's opponents (1 Tm 3:7b, Tt 1:9b). But first of all, this task is beautiful (kalon), and thus it is, according to Greek logic, worthy to be desired (1 Tm 3:1).

In New Testament times, the office of an elder was regarded as noble. However, that is rarely the case in Germany, where both the mainline churches and the majority of the free churches have difficulty finding volunteers for church leadership. Often, when a church member is approached, he or she will answer, 'I'm not that stupid. I won't do that to myself'. Obviously, these people do not see much beauty in a church leadership position: it does not bring either money or honour but rather a lot of criticism once a person is in office. It may be that in other cultures and in certain denominations, like Pentecostal churches, the office of an overseer has more prestige than it generally has in the German context.

1.Züricher Bibel, Elberfelder Übersetzung, Hoffnung für alle and Gute Nachricht (Bibleserver 2019).

2.La Bible du Sermeur and Segond 21 (Biblegateway 2019). 
The increasing number of conferences and books on church leadership have an ambivalent effect on the image of the church leader. On the one hand, leadership is presented as something attractive; on the other hand, the expectations laid on church leaders have increased, not taking into account the fact that church eldership is usually voluntary, and voluntary church elders cannot invest as much time as leadership heroes like Bill Hybels and Rick Warren.

In this article, the link between leadership and beauty is explored in an endeavour to rediscover the beauty of the church leadership office. 1 Timothy 3:1 speaks about church leadership. This article expands the topic to spiritual leadership, that is, leadership in the context of Christian spirituality. This includes leading a church, but also leading church-oriented organisations like kindergartens and mission agencies.

The research questions for this article are: what is beautiful about spiritual leadership, that is, why is it a beautiful task? Why should spiritual leaders bother about beauty?

The article starts with a short historical note about 'the neglect of (theological) aesthetics' section and 'The Great Theory of Beauty and its decline' section. In the 'theological aesthetics and transformation of the world' section, four books are introduced that deal with the link between beauty and transformation of the world. After these introductory notes, the main part of the article (see 'spiritual leadership and beauty' section) attempts to answer the research questions. The section 'a small poll' reports on a small poll providing some evidence for the conclusions drawn in the 'conclusions' section.

\section{The neglect of (theological) aesthetics}

The French philosopher Simone Weil (1909-1943) was convinced that for many people in the 20th century the most natural way to find God was through beauty. 'In everything which gives us the pure authentic feeling of beauty, there is the presence of God' (Weil 2002:150). Therefore, she criticised Christianity for having so little to say about it (Sherry 2002:69).

A more balanced view would take into account the fact that beauty may also lead in the opposite direction. 'Beauty is erotic and seductive, and can lead to idolatry; but it is also divine, and can lead to God and worship' (De Gruchy 2008:98). At least beauty can lead to God. ${ }^{3}$

Today, beauty is important on popular and social media, for example, television, Facebook and Instagram. However, we dolack a theory of beauty such as the Greeks had (Tatarkiewicz 1972:178). According to the German philosopher Wolfgang Welsch, we are currently experiencing an 'aesthetics boom' but more as 'surface aestheticization' (in De Gruchy 2008:91).

Hans Ulrich von Balthasar (1905-1988), a Catholic theologian from Switzerland, was the first modern theologian to publish

3.For example, in Kessler (2019a:55-56), it is explained how mathematical beauty may lead to the experience of spirituality. a voluminous work on theological aesthetics. The work was published from 1961 to 1969 and finally grew to seven volumes (Von Balthasar 1984). In the very first chapter, Von Balthasar (1988a) argues that the three transcendentals truth, goodness and beauty - are sisters not to be separated. If one destroys beauty, truth and goodness will perish along with it (Von Balthasar 1988a:16). In a world without beauty, goodness would also lose its power of attraction, and the proofs of a true statement would lose their power of persuasion (Von Balthasar 1988a:17). Thus, according to Von Balthasar, aesthetics is essential if one wants to retain logic and ethics. Otherwise one will arrive at the following exclamation: 'truth is a lie, morality stinks, beauty is shit' (in Cilliers 2011:260).

In the Catholic tradition, and especially in the Orthodox tradition, the doctrine of the beauty of God is still alive; however, this topic is almost totally neglected within the Protestant tradition (Von Balthasar 1988a:42, Sherry 2002:60). Two major exceptions are Jonathan Edwards (1703-1758), the father of the so-called New England theology (Sherry 2002:12-14), and Karl Barth (1886-1968, Switzerland), probably the most influential Protestant theologian of the 20th century. ${ }^{4}$ In his Church dogmatics, Barth at least deals with the beauty of God (Barth 1975:733-752), but he is still cautious about the term 'God's beauty' and does not dare to treat it as a topic on its own. 'We speak of God's beauty only in explanation of His glory. It is, therefore, a subordinate and auxiliary idea' (in ed. Thiessen 2004:316). For Barth, beauty is an explanation of his glory and not its equivalent. By contrast, for Von Balthasar beauty is far more: it is transcendental and therefore a constituent of God's glory. According to De Gruchy (2008:113-114), this is the fundamental difference between Balthasar's aesthetics and Barth's aesthetics.

The New England theologian Jonathan Edwards tied his discussion of aesthetics to the role of the Spirit within the Trinity as a beautifier (Sherry 2002:12). The 'spiritual leadership and beauty' section returns to this topic.

One reason why theological aesthetics was neglected in Protestant theology is that Protestantism stresses the 'theology of the cross', and that seemed to be incompatible with aesthetics. Some theologians demonstrate that both perspectives can be brought together. Actually, Von Balthasar and Barth in their aesthetical approach proclaim the beauty of the cross (De Gruchy 2008:122). Von Balthasar calls it 'the most sublime of beauties - a beauty crowned with thorns and crucified'. ${ }^{5}$ According to Cilliers (2011:262) 'the ugliness of the cross is the strange "beauty" of God'. 'Through the lens of faith the ugliness of the cross is transformed into a different type of beauty' (Cilliers 2011:267). ${ }^{6}$ Thus, a theology of the cross does not necessarily exclude theological aesthetics.

4.As a matter of fact, neither Von Balthasar nor Barth quote Edwards. Von Balthasa (1988a:49) erroneously named Karl Barth as the first Protestant theologian to deal with God's beauty (De Gruchy 2008:111).

5.English quote from De Gruchy (2008:122)

6.The German theologian Jürgen Moltmann discusses the 'glory of the crucified God' (in ed. Thiessen 2004:316). He argues for a redefinition of beauty, because the Holy 
Another reason for the neglect of aesthetics is the fact that there is no longer a theory of beauty - which leads us to the next section.

\section{The great theory of beauty and its decline}

The title of this section is borrowed from the Polish philosopher Tatarkiewicz (1972), who wrote a concise survey on this theory. Umberto Eco (1932-2016, Italy), a professor of literature and author of historical novels, published a 'beautiful' book The History of Beauty. In this book, Eco (2017) provides a number of sources for the understanding of beauty in different epochs.

In classical Greek culture, beauty was 'all that pleases, arouses admiration, or draws the eye' (Eco 2017:39.41). Two aspects are to be mentioned.

\section{Harmony and proportion}

Tatarkiewicz (1972:167) wrote about the Great Theory of European aesthetics', which he defined as follows: 'beauty consists...in the proportions and arrangement of the parts' (Tatarkiewicz 1972:166), harmonia and symmetria. This Great Theory was initiated by the Pythagoreans. They found the properties and relations of harmony in numbers (Tatarkiewicz 1972:167). 'Pythagoras marks the birth of an aestheticmathematical view of the universe' (Eco 2017:61). Plato took over the Pythagorean idea that beauty consists of 'harmony and proportion' (Eco 2017:48). ${ }^{7}$ Today, some elements of this understanding of beauty are still recognisable in the discussions about the Golden Ratio (Corbalán 2012).

\section{Functional beauty}

According to Plato's contemporary Xenophon, something is beautiful if it fits its purpose. ${ }^{8}$ This is the functional aspect of beauty. 'Beauty consists in the adequacy of things to their purpose' (Tatarkiewicz 1972:173). ${ }^{9}$ If something is dysfunctional or does not serve its purpose, it cannot be beautiful. In this sense, a crystal hammer is ugly because the material does not conform with the purpose of a hammer (Eco 2017:88). These connotations are probably behind the use of the word kalos in 1 Timothy 3:1: The task is kalos (i.e. beautiful and good) if it fits its purpose, the purpose of the church.

The Great Theory of Beauty was then further developed by Augustine, Thomas Aquinas and others. But it is no longer considered valid; its decline started in the 18th century (Tatarkiewicz 1972:174). The challenge is that today there is

Spirit, who is the beauty of God, was present with Christ in the ugliness of the cross (Van den Bosch 2014:852).

7.Plato, in his work Symposium, speaks about the 'glance' that sees 'true beauty, the divine beauty' (Eco 2017:41), which he connects to virtue and truth. Here we see the above-mentioned troika: 'the true, the good and the beautiful'.

8.'If therefore a thing is well-suited to its purpose with respect to this, it is beautiful and good'. This wording probably goes back to Xenophon's teacher Socrates.

9.This functional aspect used to be a supplement to the Great Theory; it became independent only in the 17th century (Tatarkiewicz 1972:173). no theory in sight to fill the empty space after the decline of the Great Theory of Beauty. 'the word and concept beauty have been retained in colloquial speech; however, they are used in practice rather than in theory' (Tatarkiewicz 1972:178).

Eco (2017:14) argues that 'beauty has never been absolute and immutable but has taken on different aspects depending on the historical period and the country'. A practical example of this statement was provided by the journalist Esther Honig, who conducted an interesting study in 2014. She sent a photo of herself to various people in different countries asking them to make her look beautiful using Photoshop. The results demonstrate that on the one hand, ideals of beauty vary from country to country; on the other hand, they still have some things in common (Gofeminin 2014).

\section{Theological aesthetics and transformation of the world}

There are some publications on the link between leadership and aesthetics. For example, the Polish authors Hatch, Kostera and Kozminski (2007:1-11) write about 'the aesthetic of leadership'; Hansen, Ropo and Sauer (2007) deal with 'aesthetic leadership' and provide a good survey of literature on this topic. Because the focus here is on the theological aspects of aesthetics, this section discusses four theological books dealing with aesthetics and transformation of the world.

\section{Bohren: Practical theology as theological aesthetics}

The practical theologian Rudolf Bohren (1920-2010) was of Swiss origin but spent most of his academic career in Germany, especially in Heidelberg. In his book God becomes beautiful (Dass Gott schön werde), Bohren (1975) lays the groundwork for his understanding of practical theology. The title is surprising because it refers to the future rather than the present. Usually, we would say: 'God is already beautiful' and not 'God becomes beautiful'. Bohren's approach is pneumatological, founded on the work of the spirit. Because the spirit is a recreator, a pneumatological practical theology must be future-oriented - looking at the new earth and the new city (Bohren 1975:14). Practical theology reflects 'God becoming practical', which is understood in the aesthetic sense of 'God becoming beautiful' (Bohren 1975:14). Thus Bohren (1975:15) describes practical theology as 'theological aesthetics' (the subtitle of his book), which has the task of shaping the world according to the laws of beauty. ${ }^{10}$ Bohren (1975:142-143) contrasts the 'laws of beauty' with 'the law of ugliness', which entered the world in the fall. Thus Bohren's approach 'is about the beautification of God in the midst of ... ugliness' (Cilliers 2011:266). ${ }^{11}$

10.'Praktische Theologie gilt demnach der Formierung der Welt nach den Gesetzen der Schönheit' (Bohren 1975:143).

11.Because Bohren's work was never translated into English, he is nearly ignored outside the German-speaking countries. The Dutch author Heitink (1999:112) and the South African author Cilliers (2011:266) are the only references I am aware of Neither is Bohren's work mentioned in Thiessen's reader on Theological aesthetics, Neither is Bohren's work mentioned in Thiessen's reader on Theological aesthetics,
nor by Sherry (2002) or De Gruchy (2008), although the latter came to conclusions similar to Bohren. 


\section{Sherry: The Holy Spirit and beauty}

In 1992, the British theologian Patrick Sherry published his book Spirit and beauty (2002), exploring the links between the Holy Spirit and beauty - another neglected area of discussion. ${ }^{12}$ As Sherry (2002:78) points out, typically two links between the Spirit and beauty are discussed: (1) the role of the spirit in creation (Gn 1:2) and (2) artistic talents as gifts of the Holy Spirit, for example, in the craftsman Bezalel (Ex 31:2-5). In addition, Sherry places a strong emphasis on the Spirit's role as a beautifier (see below).

Sherry (2002:142) then discusses the role of the spirit in the final transfiguration of the cosmos, indicated by Psalm 104:30: ' $[w]$ hen you send forth your Spirit, they are created, and you renew the face of the earth'. Thus Sherry (2002), like Bohren, emphasises the eschatological role of the Spirit and of beauty:

$[B]$ eauty has an eschatological significance, that in it we glimpse the future transfiguration of the cosmos which is symbolized in the New Jerusalem and the new heaven and earth prophesied in the Book of Revelation (anticipated by Isa. 65:17). (p. 142)

\section{De Gruchy: Theological aesthetics in the struggle for justice}

In 2001, the South African theologian John W. de Gruchy (Cape Town) published a voluminous book Christianity, art and transformation. De Gruchy (2008:1) sees a connection between ugliness and oppression, and between beauty and redemption. Thus his focus in this book is 'the redemptive power of beauty' (De Gruchy 2008:97-135), the contribution of aesthetics to the process of societal transformation. De Gruchy (2008) emphasises the unique contribution of theology to aesthetics:

Theological aesthetics is not a sub-discipline of philosophical aesthetics, but an enquiry that assumes the biblical grand narrative of creation and redemption, of paradise lost and paradise regained, of incarnation, death and resurrection, of the gift of the Spirit and the hope of a 'new heaven and earth'. (p. 101)

Many people consider aesthetics as a sort of luxury, pursued and enjoyed by the elite only. Thus, De Gruchy (2008:129) clearly states: 'Theological aesthetics does not encourage flight from the world but assumes Christian participation in God's mission to transform the world'. ${ }^{13}$

As evidence, the example of Archbishop Desmond Tutu is mentioned and how he was attracted to the icon of the transfiguration (Mt 17:1-13). De Gruchy (2008) states:

In the midst of the ugliness of apartheid and the struggle to bring about its downfall, the icon of transfiguration opened a window of hope through which the transformation of South Africa could be anticipated. (p. 125).

12. Sherry concedes that the East has 'done more to develop a theology of beauty specifically related to the Holy Spirit' (Sherry 2002:91) and that 'many Eastern manifesting the Word' (Sherry 2002:91).

13.De Gruchy (2008:133) argues that also in the case of von Balthasar 'his theological aesthetics did not imply any withdrawal from the need to work for justice in the world'.
De Gruchy calls this the 'transfiguration spirituality', that is 'the spirituality of seeing the splendour of God even in the midst of ugliness and pain' (De Gruchy 2008:125). This spirituality is transformative and 'can only be understood in the light of the gift of the Spirit' (De Gruchy 2008:125).

\section{Boren: The beauty of God's mission}

US theologian Scott Boren completed a doctoral thesis on the 'missional church and missional leadership in the light of theological aesthetics' (Boren 2018: subtitle). His research question was 'how has the theological aesthetics informed the way missional pastors lead?' (Boren 2018:18). Boren conducted an empirical study by interviewing four pastoral leaders who espoused 'the view of missional church as triune participation' (Boren 2018:128).

One motivation for his research was the observation that sometimes Christian leaders are so convinced of the truth and goodness of the missional approach that they 'end up forcing people in that direction, often using guilt, shame, and manipulation' (Boren 2018:23). Boren (2018) is convinced that this happens if theological aesthetics is neglected. In his (2018) concluding section, he argues:

The movement toward missional church depends...upon the church and its leaders' capacity to participate in the telos of beauty. This fosters a way of leadership that is in and of itself beautiful... (p. 234)

\section{Spiritual leadership and beauty}

This section provides a theoretical theological answer to the research question about the link between spiritual leadership and beauty. It draws heavily from the above-mentioned works of Bohren, De Gruchy and Sherry.

\section{Spiritual leaders are beautifying the church and beyond}

The first thesis of this article is that spiritual leaders are beautifying the church and beyond. This conclusion has to be developed in four steps:

1. The spirit is the real leader of the church

In 1961, Bohren gave a lecture about church leadership (reprinted in Bohren 1969). He raised the question: 'who leads the church?' With reference to John 16:3, Bohren (1969:170) argues that the Holy Spirit leads the church. The seven letters of Revelation are dictated by the risen Christ but they end with the words: 'hear what the Spirit says to the churches' (Rv 2:7, 11, 17, 29; 3:6, 13, 22). Christ is the head of the church ( $\mathrm{Col} 1: 18)$ but because Christ sits next to his father, he reigns over his church via the spirit until he returns to the earth (Bohren 1969:170). At first glance, this distinction might look like nit-picking because, after all, the spirit and Christ belong to the Trinity. But Bohren (1975:27, 186-189) lists some practical implications of this change of perspective. 


\section{Church leaders are partaking in the work of the spirit}

The German theologians Böhlemann and Herbst (2011) published a handbook on church leadership entitled 'Spiritual leading'. In their definition of spiritual leadership, they refer to Bohren's teaching: 'spiritual leadership is leadership through the Holy Spirit, executed...by the leaders installed by the Holy Spirit' ${ }^{14}$

According to this definition, the connection between church leadership and the Spirit already starts with the selection process. There are many organisational ways of finding new leaders in the church, but whatever process we use, we trust (hope) that ultimately these leaders have been chosen by the spirit (Ac 20:28: 'in which the Holy Spirit made you overseers'). Furthermore, the spirit distributes gifts in connection with leadership (e.g. 1 Cor 12:28, Eph 4:11). So we may conclude that the spirit chooses the church leaders and enables them to exercise the leadership task. These leaders should be aware that the spirit is the leader of the church and that in their task of leading the church, they have the privilege of participating in the work of the spirit.

\section{The spirit is beautifying the church and beyond}

Already the reformer John Calvin wrote about the beautifying work of the Spirit. With reference to Genesis 1:2, Calvin (1845; Cf. Sherry 2002:12) concluded:

[F] or it shows not only that the beauty which the world displays is maintained by the invigorating power of the Spirit, but that even before this beauty existed the Spirit was at work cherishing the confused mass. (Institutio, i.13 §14)

In his Discourse on the Trinity, John Edwards describes various offices of the spirit, one of which is to 'beautify all things' (n.d.:123). Edwards then refers to Job 26:13: 'by his spirit garnished the heavens'.

Both Bohren (1975) and Sherry (2002) place great emphasis on the fact that the spirit is beautifying the world..$^{15}$ Bohren (1975:94-125) mentions four areas in which God's spirit works according to the laws of beauty, against the law of ugliness: creation, culture and arts, history and the church.

Sherry (2002:12) even uses the noun 'the spirit as beautifier'. He does so in analogy to the well-known phrase 'the spirit as perfecter' (Sherry 2002:81), used by St. Gregory of Nazianzus (2002:5). ${ }^{16}$ As noted above, both Bohren and Sherry emphasise the eschatological dimension of beautifying.

From the statements, (1) the spirit is the real leader of the church, (2) church leaders are partaking in the work of the spirit and (3) the spirit is beautifying the church and beyond, we can draw the following conclusion.

14.German original: "Geistliche Leitung ist Leitung durch den Göttlichen Geist vollzogen in der Gemeinschaft der Heiligen durch die vom Geist eingesetzte Leitung' (Böhlemann \& Herbst 2011:22).

15.Von Balthasar (1988b:232-236) speaks about the spirit as 'glorifier', glorifying Jesus Christ.

16.Sherry argues that this is a concept he found in theologies of different times and places: early Alexandria, 18th century New England and 20th century Russian Orthodoxy (Sherry 2002:4).
4. Spiritual leaders are beautifying the church and beyond

So far, this is a theological statement and not a phenomenological one. Unfortunately, this statement is not true for every spiritual leader. There are, for example, spiritual leaders, who, in their pursuit of power, make the world uglier than before (Kessler \& Kessler 2017; Kessler 2019b).

How can this statement (4) become visible? Leaders usually want to improve the organisation they are leading. They envisage a situation that is better than the current situation and take steps to move towards this situation. By doing this, they beautify the organisation and the context in which they work. It was noted previously that leaders need spiritual gifts in order to exercise their leadership task. 'The spiritual gift has the mission to form the world and the church according to the laws of beauty'. ${ }^{17}$

\section{Spiritual leaders should strive for beauty}

It is taken for granted that church leaders should 'be fellow workers for the truth' (3 John 8). It is also expected that they strive for goodness by being good role models (see, e.g., the above-mentioned list of virtues in $1 \mathrm{Tm} 3$ and $\mathrm{Tt} 1$ ). The second thesis of this article is: spiritual leaders should strive for beauty as diligently as they strive for truth and goodness. As Von Balthasar (1988a:16) rightly observes, the troika (truth, goodness and beauty) cannot be separated. Therefore, leaders have to deal with beauty because otherwise truth and goodness will also be forfeited. De Gruchy (2008), taking up Balthasar's statement about the inseparability of the troika, puts it this way:

Truth without goodness and beauty degenerates into dogmatism, and lacks the power to attract and convince; goodness without truth is superficial, and without beauty ... it degenerates into moralism. Alternatively, we could say that truth and goodness without beauty lack power to convince and therefore to save. (p. 107) $)^{18}$

What does this statement mean in practice? De Gruchy (2008:2) believes in the transformational potential of the arts and their importance for Christian praxis and provides many examples from South Africa and beyond. Boren (2018:199-227) identifies some ways pastoral leadership can work towards the goal of missional beauty.

Hanna Schrenk, a student at our Academy of Christian Leadership, pointed out another application of 'leaders should strive for beauty'. Hanna leads a kindergarten in Southern Germany. They started to transform their rooms towards a certain aesthetic ideal. One reason is that today in Germany children spend much more time in the kindergarten than they did a decade ago. It used to be in the mornings only, but today it is often from 08:00 to 17:00 (Hollmann 2016:3). Thus, the kindergarten rooms have a greater influence on the children's development than in the past. In an aesthetic 17.'Das Charisma hat die Aufgabe, Welt und Gemeinde nach den Gesetzen der Schönheit zu gestalten' (Bohren 1975:145)

18.Also quoted in Boren (2018:62). 
environment, children would develop more motivation and enjoyment of life (Hollmann 2018:2). Their aesthetic ideal is to 'clear the rooms' ('Räume klären'). This means first to tidy up the rooms and then to transform them into clear and transparent spaces ('less is more'), but also to create certain stimuli for the children. ${ }^{19}$ In an aesthetic environment, the kindergarten children develop an intrinsic motivation to keep order. Thus, aesthetics obviously has an influence on moral development.

The aesthetic aspect of leadership cannot be reduced to decorative elements like putting flowers and nice candles on the table. It is a much more holistic approach. Thus, it is an essential part of leadership and cannot be completely delegated to somebody outside the leadership team, just as true teaching cannot be outsourced (e.g. see Ac 6:2).

\section{A small poll Methodology}

In Germany, we have a biennial conference on Christian leadership (www.kcf.de). There are about 3500 attendees from the business world, churches, Christian nongovernment organisations, etc. During KCF19 in Karlsruhe, 28 February-01 March 2019, we conducted a survey with the following two questions: (1) what is beautiful about leading? and (2) what is not beautiful about leading? This little 'survey' (strictly speaking, we were just collecting some answers) was not restricted to spiritual leaders. We can assume that the participants of KCF19 identified with the Christian perspective of the congress, but most of them had secular jobs. Thus, we put the question about leadership quite generally and did not distinguish between different branches or between paid and voluntary leadership positions. We kept it simple because we were looking for spontaneous answers. We just provided the Bible verse 1 Timothy 3:1 and asked the two above-mentioned questions. The participants wrote their answers on small index cards and put them into two different boxes (1 beautiful and 2 not beautiful). Some participants just wrote one issue on one card and others wrote several issues on one card. As far as we could tell from the handwriting, only one person put two cards into box B.

\section{Results on the question 'what is beautiful about leading?'}

We collected 116 index cards on the first question. The highest score was given to 'human beings' (69 times). Leaders enjoy working together with other people, and they especially enjoy it when they can empower other people by finding their strengths and then supporting them (mentioned 36 times). They enjoy it when people grow. The apostle Paul obviously also knew about this joy. He wrote to the Thessalonians: 'for you are our glory and our joy' (1 Th 2:20, cf. Phlp 2:2).

19.There is some parallel to Calvin's explanation of Genesis $1: 2$ : first the spirit had to contend with the tohubohu and then the spirit created something clear, functional, meaningful and beautiful.
The second highest score was for the opportunity to shape the future. Actually, 23 participants used the German word 'gestalten' (shape). In Germany, people do not like the word 'power' and often use the word 'shaping' instead. Eleven index cards mentioned 'responsibility' as a beautiful facet of leadership (which is interesting, because this was also a topic on the negative side - see below).

Twelve index cards had an explicit link to God or Jesus. They mentioned that it is beautiful to have a task from God, to work for God's honour, to participate in God's work. One expected a reward in heaven. One participant mentioned the opportunity 'to observe God at work'.

\section{Results on the question 'what is not beautiful about leading?'}

We collected 47 index cards on this question. The highest score went to pressure and stress (14 times). Leaders have to work hard, and they often have to work more than others. The second highest score was for the issue of responsibility (12 times), amongst which was to take responsibility for hard and nasty decisions. The third highest score was for the social isolation of leaders (six times). Although many leaders like to work with people (see above), they know about the loneliness of leaders.

\section{Conclusions}

Firstly, beauty is as important as truth and goodness. Thus, leaders should strive for beauty as diligently as they strive for truth and goodness. The leadership task cannot be completely delegated to people outside the leadership team.

Secondly, spiritual leadership is a beautiful task because spiritual leaders are beautifying the church and beyond. They partake in the work of the spirit, who is a beautifier. This has a future-oriented, eschatological dimension: leading into a better, more beautiful world.

This is not to be understood in a naïve way. Christian leaders often deal with the ugliness of the world, amidst chaos, crime, corruption, abuse of power, etc. But in their service they contribute to the beautification of the world, working against the 'law of ugliness' (Bohren 1975:143).

In practice, the beauty of leadership can be experienced in different ways, for example, by helping people grow, by seeing beautiful results or, as one participant in the survey put it, 'by observing God at work' and being part of it.

\section{Acknowledgements Competing interests}

The author declares that he has no financial or personal relationships that may have inappropriately influenced him in writing this article.

\section{Author's contributions}

V.K. is the sole author of this research article. 


\section{Ethical considerations}

This article followed all ethical standards for research without direct contact with human or animal subjects.

\section{Funding information}

The research received no specific grant from any funding agency in the public, commercial or not-for-profit sectors.

\section{Data availability statement}

Data sharing is not applicable to this article as no new data were created or analysed in this study.

\section{Disclaimer}

The views and opinions expressed in this article are those of the author and do not necessarily reflect the official policy or position of any affiliated agency of the author.

\section{References}

Barth, K., 1975, Kirchliche dogmatik, zweiter band: Die Lehre von Gott, 1. Halbband, 5th edn., Theologischer Verlag, Zürich.

Biblegateway, 2019, viewed 31 May 2019, from www.biblegateway.com.

Bibleserver, 2019, viewed 31 May 2019, from www.bibleserver.de.

Bohren, R., 1969, 'Die leitung der gemeinde', in R. Bohren (ed.), Dem worte folgen: predigt und gemeinde, pp. 169-188, Siebenstern, München.

Böhlemann, P. \& Herbst, M., 2011, Geistlich leiten: Ein handbuch, Vandenhoeck \& Ruprecht, Göttingen

Bohren, R., 1975, Daß Gott schön werde: Praktische theologie als theologische ästhetik, Chr. Kaiser, München.

Boren, M.S., 2018, The beauty of God's mission: Missional church and missional leadership in the light of theological aesthetics, The Center for Community \& Mission, Woodbury.

Calvin, J., 1845, The institutes of the Christian religion, transl. H. Beveridge, Christian Classics Ethereal Library, Grand Rapids, MI.

Cilliers, J., 2011, 'Fides quarens pulchrum: Practical theological perspectives on the desire of beauty', Scriptura 108(3), 266-267. https://doi.org/10.7833/108-1
Corbalán, F., 2012, The golden ratio: The beautiful language of mathematics, RBA Coleccionables, London.

De Gruchy, J.W., 2008, Christianity, art and transformation: Theological aesthetics in the struggle for justice, Cambridge University Press, Cambridge.

Eco, U., 2017, The history of beauty, Rizzoli International Publications, New York, NY.

Edwards, J., n.d., Discourse on the Trinity, viewed 06 June 2019, from edwards.yale.edu.

Gofeminin, 2014, Was ist eigentlich schön? Ein photoexperiment überrascht alle!, viewed 14 August 2019, from www.go.feminin.de/gespraechsstoff/ein-photosphopexperimentund-sein-überraschendes-ergebnis-s533326.html.

Grünzweig, F., 1996, 1. Timotheusbrief, Edition C Bibelkommentar, Hänssler, NeuhausenStuttgart.

Hansen, H., Ropo, A. \& Sauer, E., 2007, 'Aesthetic leadership', The Leadership Quarterly 18, 544-560. https://doi.org/10.1016/j.leaqua.2007.09.003

Hatch, M.J., Kostera, M. \& Kozminski, A., 2007, The three faces of leadership: Manager, artist, priest, Blackwell Publishers, Malden.

Heitink, G., 1999, Practical theology: History, theory, action domains, Wm. B. Eerdmans, Grand Rapids, MI.

Hollmann, E., 2016, Bildungs-Landschaften: Die kita im wandlungsprozess, ILKEInstitut, Offenbach.

Hollmann, E., 2018, Räume klären in der kita, ILKE-Institut, Offenbach.

Kessler, M. \& Kessler, V., 2017, Die machtfalle: Machtmenschen - wie man ihnen begegnet, 5 th rev. edn., Brunnen, Gießen.

Kessler, V., 2019a, 'Spirituality in mathematics', Journal for the Study of Spirituality 9(1), 49-61. https://doi.org/10.1080/20440243.2019.1581384

Kessler, V., 2019b, 'The dark side of servant leadership: Power abuse via serving', in L. Bouckaert \& S. Van den Heuvel (eds.), Servant leadership, social entrepreneurship and the will to serve: Spiritual foundations and business application, pp. 103-121, Palgrave Macmillan, Cham.

Roloff, J., 1988, Der erste brief an Timotheus, Evang.-kath. Kommentar zum Neuen Testament, Benzinger, Zürich \& Neukirchener, Neukirchen-Vluyn.

Sherry, P., 2002, Spirit and beauty, 2nd edn., SCM Press, London.

Tatarkiewicz, W., 1972, 'The great theory of beauty and its decline', The Journal of Aesthetics and Art Criticism 31(2), 165-180. https://doi.org/10.2307/429278

Thiessen, G.E. (ed.), 2004, Theological aesthetics, SCM Reader, SCM Press, London.

Van den Bosch, D., 2014, 'Spirit, vulnerability and beauty: A pneumatological exploration', Nederduitse Gereformeerde Teologiese Tydskrif 55(2-4), 835-857. https://doi.org/10.5952/55-3-4-668

Von Balthasar, H.U., 1984, The glory of the Lord. A theological aesthetics, Seven volumes, T\&T Clark, Edinburgh.

Von Balthasar, H.U., 1988a, Herrlichkeit. Eine theologische ästhetik. Bd. 1 Schau der gestalt, 3rd edn., Johannes-Verlag, Einsiedeln.

Von Balthasar, H.U., 1988b, Herrlichkeit. Eine theologische ästhetik. Bd. 3,2 Theologie, Teil II: Neuer bund, 2nd edn., Johannes-Verlag, Einsiedeln.

Weil, S., 2002, Gravity and grace, Routledge, London. 